\title{
THEOLOGY, THE ENCHANTED UNIVERSE, AND DEVELOPMENT - REFLECTIONS AROUND A ZAMBIAN CASE STUDY IN THE LIGHT OF CHARLES TAYLOR'S A SECULAR AGE
}

\author{
Anthony Balcomb \\ University of KwaZulu-Natal
}

\begin{abstract}
The fact that development discourse is dominated by the Western categorisation of 'developed' and 'developing' nations indicates the hegemony of the West when it comes to understandings of development. While this understanding can be contested it is hardly appropriate to change the rules of the game when it comes to benchmarks of development in terms of standards of living, longevity and health. What must be contested, however, is the notion that all countries must follow the same paths that lead to a state of development. Charles Taylor's seminal work on secularisation suggests, following Weber, that development in the West was accompanied by secularisation which, in turn, followed the pattern of disenchantment of the universe, the removal of God, and the shift from a transcendent to an imminent frame. The expectation is that African countries will follow the same route if development is to take place. This has not happened, as Parsons' work in the Zambian copper industry indicates. Therefore development theorists need to take cognisance of the 'spiritual' realities of an African worldview.
\end{abstract}

Key Words: Development; Disenchantment; Agency; Worldview

One constantly hears the terms 'developing' and 'developed' to describe the two different kinds of nations in the world with respect to their economies. The assumption is that we all know what development means, that there is only one kind of development and that is the one defined by the West and all nations should and must aspire to such development. ${ }^{1}$ While I do not intend to contest the definition of development as outlined above it has to be recognised that the Western project of the conquest of nature, the subjugation of the environment, and the emancipation of the individual, has come at great cost. The promethean desire for absolute domination based on the principle of rationalisation has been

\footnotetext{
Jonathan Bonk has the following definition of these terms:

Developed countries have an array of visible amenities that render human life more comfortable and efficient. These countries also have the wherewithal to keep such systems going. Other countries have something less than this and so may be considered 'undeveloped', 'under-developed', or 'developing' depending upon the specific mix of their political and economic circumstances. Further, the objectives for those existing in un- or under developed states are generally seen as moving "toward some approximation of Western material and economic standards.” Jonathan Bonk, Missions and Money: affluence as a missionary problem revisited (New York: Maryknoll, 2003).
} 
2 Reflections around a Zambian Case Study in the Light of Charles Taylor's 'A Secular Age' criticised from many quarters. ${ }^{2}$ I am not at all sure, however, of the ethics of changing the ground rules of notions of progress when only one set of rules already has substantial hegemony. ${ }^{3}$ To tell 'undeveloped' countries not to conform to Western notions of development at this stage of the game is surely to invite them to embark on a path of selfdestruction. Ghandi wanted to do this with India several decades ago and was side-lined by Nehru and others. That there is a universal notion of human flourishing which is inextricably bound up with the quotidian realities of longevity, absence of poverty, and the material conditions that define a 'good quality of life', can hardly be contested. That these are determined in large part by Western medicine, Western science and technology, Western notions of democracy, and the economies of Western countries (with the possible exception of India and China), is likewise hardly contestable.

The main assumption that I wish to contest in this paper is the assumed existence of the conditions for development in the 'developing' countries, specifically Africa, that began to exist in the 'developed' countries, specifically Europe, from around the seventeenth century. It seems to me that development discourse falls into major error where it fails to recognise that the conditions for development from the point of view of theology and worldview that obtained in the Western world do not (yet) obtain in Africa (and probably in other parts of the world) and therefore there are no grounds to believe that there will be unimpeded progress toward development in Africa along the lines of the Western paradigm. Put simply, things happened in Europe and the West from around the seventeenth century that profoundly shaped the way that development has taken place there. These things have not taken place in Africa and the 'non-West' and we therefore cannot expect things to take place in the same way there. Our contribution as theologians and activists to development discourse in the 'developing world' is, amongst other things, to do the necessary analysis from a theological perspective into the processes and conditions that exist in the developed and developing world with respect to issues surrounding development and from there to make the appropriate judgments with respect to the possibilities and potentialities of development in the developing world. I emphasise the theological nature of this enterprise because the temptation to forsake the particular genius associated with our craft in favour of the social sciences is constantly present. This pressure (that is to do social science instead of theology) is particularly strong in the wake of the European Enlightenment which intellectually energised much of our understanding of development. It seems we have

2 Postmodernism, for example, while a hotly contested concept, has introduced a set of conditions which interrogate the rational foundations of the era that has largely defined for us the meaning of development. More pointedly the group of Western scholars, including Habermas and others, known as the Frankfurt School, has argued that the kind of rationality serving Western industrial civilisation is responsible for the profound sense of alienation experienced in the West. This is due to its obsession with means and its loss of certainty with regards to the value of the aims that these means are meant to achieve. This critique is taken up by Klaus Nürnberger in his recent book where he dubs the present Western civilisation as a 'self-indulgent' one where "the quest for knowledge, power, wealth, prestige and pleasure is no longer deemed a manifestation of human selfishness and arrogance to be controlled by divine authority, human ancestry, culture, or ethical tradition, but a natural phenomenon to be embraced and enhanced”. Klaus Nürnberger, Regaining Sanity for the Earth - Why Science needs best faith to be responsible [and] Why faith needs best science to be credible (Cluster Publications, 2011:36,37).

3 I say 'substantial' and not 'total' because resistance against Western notions of progress are evident. The socalled 'clash of civilisations' between the West and Islam is a case in point. Though it is doubtful whether the basic criteria of progress mentioned above concerning life expectancy, health, etc. would be contested in any context. 
largely forgotten, because of our history, to do theology when thinking about development. ${ }^{4}$ But theology has played a profound role in the history of development in the West. In what ensues I will use the work of Charles Taylor to talk (very briefly) about the shift in worldview, with the accompanying theological shifts, that provided the social and intellectual conditions for the kind of rationality that paved the way for the current hegemonic understanding of development. I will argue that the same conditions do not exist in the African context and that this should be shaping our understanding of development in the non-Western world in general and of theology and development in this part of the globe in particular. For this I will use the work of Elizabeth Parsons and her research on the Zambian copper mines, demonstrating that this research demonstrates the continued existence of a worldview that Taylor argues needed to be superseded before development along the lines of the Western model could take place. In conclusion I will refer to the work of Birgit Meyer who also comments on Taylor's use of the concept of disenchantment and offers a nuanced interpretation of this in the African context.

\section{Charles Taylor's take on Weber's Notion of Disenchantment}

In his tome of some 800 pages entitled A Secular Age Charles Taylor describes the philosophical and theological processes that took place in the West to produce the conditions in which what could be called the 'modern' human being exists. ${ }^{5}$ He describes a massive shift in worldview that has taken place in the West between the sixteenth and the eighteenth centuries and culminating in the twentieth century. The basic question he asks is how it is that in the year 1500 in Western society it was "virtually impossible not to believe in God" but in the year 2000 "many of us find this not only easy, but even inescapable". ${ }^{6}$ The essence of this shift has been from transcendence to immanence - a change that has led to the move away from an emphasis on God, the supernatural, and the afterlife to the human person and his or her material circumstances in the present life. The word that he uses to describe the process involved in this shift is the one coined by Max Weber disenchantment. While Weber emphasised the negation of an enchanted universe by emphasising the need for disenchantment in the formation of the modern (secular) worldview Taylor's emphasis is on the processes of disenchantment, the actual 'disenchanting' of an enchanted universe. He thus starts his discussion with an attempted description of the enchanted universe; 'attempted' because, as he frequently points out, it is very difficult for the modern person to understand the nature of the universe as apprehended by people in the fifteenth century.

It is impossible in such a short space to do full justice to Taylor's description of the processes involved in the disenchanting of the universe and the emergence of the modern condition. Two things seemed to dominate Weber's reflections around the rise of modernity. The first was how religious faith translated into economic practice and the second of how economic practice itself became rationalised, that is purged of influences extraneous to the forces internal to the processes of production. ${ }^{7}$ Taylor's interest is more in

\footnotetext{
$4 \quad$ For more on this issue see Anthony Balcomb, "What Theology? Whose Development? Interrogating Theology and Development in the Secular Academy”, JTSA No.12, March 2012:6-20.

Charles Taylor, A Secular Age (Cambridge Massachusetts: Harvard University Press, 2007).

Charles Taylor, 2007:25.

Weber's theory of rationalisation is especially important to this discussion. He identified four types of rationality: Practical rationality, which is to be found in people's mundane, day-to-day activities and reflects their worldly interests; theoretical rationality which involves "an increasingly theoretical mastery of reality by
} 
4 Reflections around a Zambian Case Study in the Light of Charles Taylor's 'A Secular Age'

the philosophical and theological shifts that took place. Essentially the shift from a premodern to a modern worldview involved a series of disengagements - God from the world; mind from the body; church from politics; individual from society; spiritual from the material. For Taylor disenchantment involved a number of processes on a multiplicity of levels three of which I will attempt very briefly to summarise, using the terms Taylor himself uses. First there was a change in the relation between the self and the world, second there was the imposition of human control over what was formerly perceived to be a world beyond human control, third there was a shift in relation between the individual and society. Each of one of these were undergirded by a theological shift - that is a shift in relation between the individual and God. The first Taylor calls the shift from the 'porous' to the 'buffered' self, the second he calls the 'rise of the disciplinary society', and the third he calls 'the great disembedding'. The theological shift that undergirded these was from a kind of imminent theism to providential deism.

\section{From the 'Porous' to the 'Buffered' Self - the Shift in Relation between Self and World}

Taylor's comparison of the porous self of pre-modernity with the modern, buffered self is extensive. In the space given I can hardly do justice to it. In a nutshell these conditions are to do with the boundaries, or lack of them, between the self and the world in which the self is situated. For the porous self the boundary could be likened to a permeable membrane through which things could pass relatively unhindered, for the buffered self it was a series of obstacles which resisted penetration. These boundaries, or lack of them, had a profound effect on the kind of interactions that took place between the self and the world. The fluidity between the inner and outer lives of porous selves in the enchanted universe meant the interpenetration and fusion of life worlds between entities. Separate existences were impossible. The self was intensely vulnerable to the influence of others at a variety of levels of intensity. This influence was exacerbated by the fact that the enchanted universe had an animated existence; that its objects within it were charged with meaning. This had profound epistemological implications. "In the enchanted world”, says Taylor, "charged things can impose meanings, and bring about physical outcomes proportionate to their meanings" (2007:37). This kind of exogenous meaning allows for the possibility of objects to have causal influence over other objects. Blessed objects, for example, can have positive power while evil objects can have negative power. This had a range of implications for the kind of interactions that could take place between entities. The combined effect of vital participation and exogenous meaning enables the possibility, for example, of images of people, or their body parts, having influence across time and space, for either good or bad. ${ }^{8}$ The question asked is not what, but who, is the cause of things that happen.

means of increasingly precise and abstract concepts” (Weber 1958; 293); substantive rationality involves value postulates, or clusters of values, that guide people in their daily lives; and formal rationality which involves the rational calculation of means to ends based on universally applied rules, regulations, and laws. These types of rationality are key ingredients of the bureaucratisation of society and are all characteristics of the disengaged, autonomous self motivated by the need for control (see George Ritzer, "The Weberian Theory of Rationalisation and the McDonaldisation of Contemporary Society”, www.corwin.com/upm-data/16567).

8 I had an experience that classically demonstrates this. My photograph was taken at a conference in Abidjan, Ivory Coast in 1997, without my knowing it. When, at the end of the conference, I expressed the wish not to purchase it and take it home my colleagues became extremely concerned because, they said, the image could be used in a way that could have serious consequences for my health and well-being, in spite of the fact that I could be hundreds of miles away from it. 
The level of vulnerability is vastly reduced in the buffered self. The boundary between the self and the world means the possibility of a level of disengagement between the self and the world that is impossible with the porous self. For the buffered self the mind interrogates all attempts at entry into the self from the outside world. The boundary is further reinforced by the de-animation of the universe which becomes exorcised of charged meaning. Meaning for the buffered self now lies in the inner world of the mind, not in the outer world of animate beings.

These two ways of being in the world have profound implications for one's sense of agency in the world. The porous self is one of many other, greater selves in the world. Action in such a world is therefore not only very limited - it can also lead to highly unpredictable results. You do not 'play' with a world upon which you cannot impose meaning very easily. Conversely the buffered self believes it is capable of imposing meaning and order on the world, thus making it predictable. Such a world is far easier to control. There is nothing like the belief in control to instigate the exercise of control.

Thus the advent of the 'disciplinary society'.

\section{The Rise of the 'Disciplinary Society'}

The process of ridding the universe of capricious agency and disengaging the rational self from such a universe needed to be accompanied by a makeover both of God and self. Newton had played his part in offering a worldview that subjugated the wayward forces within the universe to the sovereign will of an all powerful God under whom everything was ordered in terms of divine law. But God was still taking up too much space in the public arena and needed to be relegated to the heavens. Faith was to be a matter of the individual mind. This was done via a theology of Deism. A new attitude towards nature emerged. The untamed beast, both within the individual and in the world, needed to be subjugated by reason. The buffered self had no more fear of demons, spirits, and magic forces because it could not be 'got at' by them any longer. An analogous operation had to be done on desire. The condition of ataraxia, or stoical indifference, had to be achieved. This was done via a kind of neo-stoicism. Reason had to reign supreme. Passions had to be brought under control, violence was to be eliminated, civility was to become the norm, the instrumentalisation of reason, the universe, and science needed to take place. Descartes, one of the leading philosophical influences of the day, was, according to Taylor, obviously influenced by the Greek stoics, as was Grotius and Locke. Descartes 'utterly ruined' the notion of an ethic "grounded on an order which is at work in reality" and substituted it with an ethic "imposed by the will". To do this he adopted a "consistently mechanistic view of the material universe" and advocated the notion of humankind being the "masters and possessors of nature" (2007:130-131). "The true function of reason in the conduct of life," he said:

is to examine and consider without passion the value of all perfections of body and soul that can be acquired by our conduct, so that since we are commonly obliged to deprive ourselves of some goods in order to acquire others, we shall always choose the better (2007:135).

This surely resonates with the first or 'practical' level of rationalisation that Weber spoke of (see footnote 7):

The purpose of all of this, according to Taylor, was to reconstruct society in a fashion that afforded maximum economic benefit. 
These rational, sociable beings, meant to live together in respect of each other's life and liberty, are also meant to preserve themselves by industrious exploitation of their natural surroundings. Properly carried out, this exploitation leads to economic growth. The right to property both follows immediately from this exploitation of nature, and also makes possible improvement and hence economic growth (2007:129).

Accompanying the transition from the porous to the buffered self and the rise of the disciplinary society was that unique creation of the West - the autonomous individual, which resulted through a process which Taylor calls the 'great disembedding'.

\section{'The Great Disembedding'}

The third shift that Taylor speaks about has to do with the relationship between the individual and society. In the enchanted universe the primary agency was the social group as a whole. Participation in the world of God and spirits was done as by the entire community, for example through ritual, as one undifferentiated whole. The boundaries between individual and society and society and the transcendent were all but non-existent. Powerful invocation of the divinities leading to spirit possession cannot be accomplished by the lone individual. Such rituals were undertaken on behalf of the community by functionaries such as priests and shamans who occupied a sacrosanct spiritual order in society. The individual was unable to transcend or become disengaged from the group in which she found herself. Indeed it was impossible to imagine oneself outside of such a matrix.

Disenchantment involved a process of disembedding which led to the primary agent no longer being the society but the individual. As with the other two there was a theological dimension that undergirded this. The call by God to individuals to follow him (sic) inevitably relativises the bonds of societal control. This, according to Taylor, is the first nudge in the direction of bringing about modern individualism (2007:155). The so-called post axial religions (a word coined by Karl Jaspers) enabled such a move. Yahweh calls out Abram, Jesus calls out disciples, Buddha calls out monks. This loosens old bonds of solidarity and creates new ones. New identities are established with the construction of new reference points, new moral orders, and new language registers. The Protestant Reformation assisted in the construction of these new identities and in the disenchanting of the universe but individual freedom continued to be hampered by theistic understandings of God and traditional ties to the church. It took the eighteenth century Enlightenment to break these bonds more substantially and carry the process of disenchantment to its rational conclusion. Providential deism became a handy stepping stone between theism and atheism. It supported the newfound anthropocentrism of modernity with regards to thisworldly flourishing and paved the way ultimately for the autonomisation of the individual without cutting off completely the moral moorings provided by a theistic worldview. The Enlightenment made the final break with God by doing three things. First it established the centrality of the "organised habit of criticism" and the "political demand for the right to question everything". ${ }^{9}$ Credulity, the penchant easily to believe, was the pet aversion of the scholars of the eighteenth century Enlightenment. Second, it carried forward what had already begun in the previous century concerning the disenchantment of the universe. It had to be rid of what Charles Darwin called 'caprice'; in other words of any magic, or agency of and in itself in the world. In other words the world had to be inanimate, objectified, if it

9 Peter Gay, The Enlightenment, An Interpretation - the Rise of Modern Paganism (London:Weidenfeld and Nicolson, 1969:130,141). 
was to be understood correctly. Third, the Enlightenment elicited a passionate concern for equality and justice. All three of these things have constituted the core of the intellectual legacy of the West ever since the eighteenth century and all three have had a profound effect on the way we do theology.

All of these, and much more, were part of the process of disenchantment and the move to what Taylor calls the 'secular age'. The point that he, and even more so Weber, makes, is that this shift was an 'extraordinary achievement' that needed to be made if humankind was to understand human flourishing, in the Western sense, as it does today. The question is: What of those societies that have not accomplished the 'achievement' of secularism in the sense described above, in other words which continue to live, to one degree or another, with what now must be perceived as the 'problem' of an enchanted universe in the context of the modern understanding of development? In answer to this question I wish to turn to the work of Elizabeth Parsons.

\section{Development in the Context of an Enchanted Worldview - a Zambian Case Study}

The ubiquitous presence of an enchanted worldview in Africa has been well documented in the past and continues to be so in the present, ${ }^{10}$ its impact on theology and development less so, especially in circles where the Enlightenment worldview has hegemony. ${ }^{11}$ In this sense Elizabeth Parsons' work could be viewed as groundbreaking. Her doctoral research was done through the School of Religion and Theology at the University of KwaZulu-Natal and focused on the different understandings of development, shaped by different worldviews, in the copper mining industry of Zambia. Her research highlights not only the profound difference between the worldviews of the multinational corporations that are exploiting the mineral resources and those of the Zambians who work on the mines, but also the implications that this has for the copper mining industry and the notion of development itself. It is impossible to do justice to Parsons' work in such a short space. Suffice to say that she engaged with an astonishing 212 participants in a 108 different capacities related to the copper mining industry in Zambia - from drillers, to blasters, to mine captains, to unemployed residents, to taxi drivers, to accountants, to anthropologists, to world bank officials - over a period of three years.

The following quotation sums up the motivation behind her research.

Despite increasing and diverse global involvement of Americans in international development initiatives, inside the United States terms such as 'worldviews' and 'cosmologies' have only rather recently been associated with the word 'development.' So, it is important to be quite clear about what is at stake. People working in crosscultural settings, where so many interventions associated with the concept of development take place, can experience perceptual discrepancies that are not accounted for within general development theory or policy making but which affect what happens in practice. These discrepancies pertain to the ways in which various actors in the situations

10 See, for example, Tempels (1954), Kagame (1956), Senghor (1961) Taylor (1975), Mbiti (1992), Bediako (2000), Ellis and Ter Haar (2004), Ashforth (2000, 2005).

11 Alternative viewpoints are rare, for example, in the secular university. A recent publication Mission in an African way - a practical introduction to African Instituted Churches and their sense of mission, T Oduro, H Pretorius, S Nussbaum, B Born (eds.), Christian Literature Fund, 2008, attempts consciously to present a position antithetical to the Enlightenment paradigm in the interests of being sympathetic to the African Independent Church tradition. 
understand how the world works. Simultaneously such discrepancies involve deep seated values issues. What then happens as a result of discordant understanding makes a difference morally and theologically. ${ }^{12}$

From the understanding of the mineral in question to the interpretation of causes of accidents to interpretations of privatisation to understandings of the entire mining enterprise itself, Parsons' research demonstrates that Zambians continue to use their indigenous, enchanted worldview to impute meaning in spite of the attempts by mining companies to impose a more 'rational' interpretation. The mermaid guardian of the waters was behind different levels of productivity, jealousy and witchcraft were behind accidents, and alienation of snakes was behind the diminution of success in the mining enterprise. This does not mean that rational explanations did not also play a part, but that they were not the whole story.

The point that Parsons is at pains to make about these differences of understanding is that they impact on the industry itself in such a way that should make them of vital concern to its 'captains'. For example, she argues, this particular clash of understandings is manifest in protective measures taken against accidents. Where the 'rational' measures of wearing protective gear was advocated by the mine owners these would not work to prevent the cause of the accident in the first place, which was often seen by the miners themselves as being related to witchcraft.

Another area of crucial difference in understanding is to do with depictions of material reality. Whereas in the Western paradigm many of the goods associated with progress are items that have a utilitarian value and are a means to a further end (these include cell phones, laptops, vehicles, meetings, etc.). From a Zambian perspective they gain fetish value and become ends in themselves. This is reminiscent of the classical cargo cult syndrome identified so long ago in colonial history and puts an entirely different spin on the whole notion of development. A holistic notion of development which emphasises certain processes whose end result is empowerment and freedom is lost in a context where the processes themselves become ends and not means. This had disastrous implications in the Zambian context when the privatisation debate came to the fore. If the material object is an end in itself and not simply a means to an end then the mines with all their accoutrements are ends in themselves and not a means to an end of a better economy. Parsons suggests that this inherently different understanding of the value of material objects played a role in the failure of Zambians to make a success of the mining industry when they originally gained control of it. ${ }^{13}$

Parsons is clearly intent not only on attempting to demonstrate the impact of an enchanted worldview on the copper mining industry in Zambia but also on using it to problematise the concept of development and, specifically, to raise questions about Western notions of development.

\section{Development and Disenchantment - Relating Taylor and Parsons}

12 Elizabeth Parsons, What Price for Privatization? Cultural encounter with development policy on the Zambian Copperbelt (New York: Lexington Books, 2010), 7.

13 The dynamics of a Western style economy are universally understood in the West, but when imported to a context with an enchanted worldview they take on a completely different meaning. The classical expression of this is the stock market. When the market is communicated in personalised terms and bulls and bears rage through its corridors it is difficult for those with an enchanted worldview to understand this in any other way except through the influence of spiritual forces. 
An underlying question for this discussion is whether disenchantment is necessary for development. I have juxtaposed Taylor and Parsons in order first of all to demonstrate that disenchantment has not taken place in the fashion that Taylor describes in the West. This obviously raises the question first whether the (enchanted) phenomena that Parsons describes on the Zambian copper mines can be related to the set of conditions that Taylor describes as characteristic of the enchanted universe in the European situation - that is the existence of the porous as opposed to the buffered self, the perceived hazards entailed in entering into the terrain of imposing control over the environment in order to exploit it, and the embedded, as opposed to autonomous, nature of the human being within society. Second, it raises the obvious question whether development in the Western way would be possible in such a situation, assuming the validity of Taylor's arguments concerning Western conditions for development.

While it is not possible to make any categorical assertions about the relationship between the conditions outlined by Taylor and the Zambian situation one can surely assert, on the basis of Parsons' research, that an enchanted worldview does exist in the Zambian situation and that it is having an impact on the copper mining project. Moreover Parsons' description of the nature of this impact resonates quite strongly with Taylor's descriptions of the enchanted universe. Her language approaches that of Taylor's when she talks about the 'malleable material boundaries' that exist between the self and the world, to the extent that there is a belief that individuals can take on different creaturely forms (2010:144). Taylor's reflections around the supreme epistemological vulnerability of the porous self is echoed in the question "How could one ever be sure of reality when a host of principalities and powers routinely made themselves felt, prompted by unknown motives?” (2010:185), and disenchantment is implicit in her argument that "a perspective that concentrates on mastering (more so than reverencing) its environment is in a stronger strategic position to organise and change the outer world than is a society that generally sees things quite differently" (2010:193). This, in turn, will impact fundamentally on the notion of agency in the workplace. The existence of other sources of power in the workspace constantly poses situations that would affect one's willingness and ability to make interventions into such space, at least without taking the necessary precautions.

[W] here power is understood to reside can make a monumental difference in practical, cross-cultural work settings. Understanding ultimate power as residing in physical places overseen by spiritual forces is very different from conceiving of ultimate power as vested in processes devised by the creative will of individuals and groups. When disparate sources of power engage with each other - especially when they are understood within different cosmologies - complications of incalculable proportions can result (2010:188).

There are thus resonances between Taylor's thesis and Parsons' research on a multiplicity of levels. It is likely, for example, that Taylor's reflections around the porous and buffered selves might also throw interesting light on comparisons between the perspective of the Zambians themselves and the Western based owners and controllers of the copper mining industry. Similarly her assertion about different understandings between expatriates and locals concerning means and ends around the industry (mentioned above) would also have profound impact on issues to do with productivity and profit, though this has more resonance with Weber's understanding of rationalisation in the workplace than Taylor's description of the enchanted universe.

The set of (disenchanted) conditions that Taylor describes as being necessary for 'modern' notions of development to flourish are constantly, both in his words as well as 
Weber's, framed in terms of spectacular achievement. The implication is that this kind of development could not have taken place without disenchantment and that disenchantment itself was a long and difficult process. Also implied is that the 'natural' condition of humankind is one of enchantment ${ }^{14}$ and that this condition needed to be overcome to achieve development. For the purposes of this essay I am merely mooting such a thesis by way of outlining some of the arguments put forward by Taylor and juxtaposing these with Parsons' research, as I have attempted to do above. If, however, this scenario is valid then there are clearly numerous implications for development studies in the so-called ‘developing' world.

\section{Conclusion}

I have attempted in this article to draw out some of the implications of Charles Taylor's $A$ Secular Age for development studies by applying them to a particular case study. The import of Taylor's thesis is that development, in the Western sense, requires a set of conditions that are to do with the fundamental way that we perceive, and live in, the world. The implication is that those that do not have this - that is who have not been through the processes that constitute a 'disenchanted' - will not be in a position to 'develop' in the way that the West has developed. This raises a host of questions that are relevant for development theory, not least of which are the definitions of development itself and how societies that live with an enchanted worldview negotiate the demands that modernity places upon them. While it might be argued that there is really no other show in town when it comes to development other than that offered by the West there are nevertheless substantial questions being asked about the accompanying devastating consequences of Western notions of development, for example to the environment. While critiques of the Western worldview have been around ever since the notion of modernity itself came into being there is an increasing body of work that either attacks some of the basic foundations of the Western worldview or that at least attempts to seriously accommodate some of the insights that have emerged as a result of the advent of postmodernism. An example of the first is to be found in the work of the anthropologist Tim Ingold which poses fundamental questions about an approach that is based on the kind of disembedding that Taylor describes and constantly poses the alternative of an indigenous (read 'enchanted' or 'animist') perception of the environment as being more appropriate for human beings, ${ }^{15}$ and an example of the latter in the recent work of Klaus Nurnberger who offers a critical assessment of modernity and postmodernity, attempts to find what is best in both, and suggests a way forward theologically (2011). ${ }^{16}$

14 Bediako (1995) and others have argued that the primal universe, which is another expression for the enchanted universe, by definition exists as the first or primary manifestation of a human being's cosmology.

15 Tim Ingold, The Perception of the Environment - essays in livelihood, dwelling, and skill, (London and New York: Routledge, 2000), and Being Alive - Essays on Movement, Knowledge and Description (Abingdon: Routledge, 2011).

16 Nürnberger's is an intensive, detailed, and careful evaluation of the contribution of science and theology in the pursuit of truth. While acknowledging and giving some value to postmodern proposals and being fully cognisant of the ways in which modernity has given rise to potentially disastrous consequences for the planet his argument is that modernity is, indeed, the only show in town when it comes to producing the goods needed for human flourishing. In my opinion, however, his treatment of pre-modern understandings of reality is too dismissive and sometimes too caricatured. The rationalist paradigm which he apparently finds it so necessary to work within needs the challenge of an alternative set of proposals which can be found in the work of such scholars as Ingold. Ingold, with others (see, for example, Morris Berman The Reenchantment of the World, 
There has been considerable interest in the ways in which modernity has been negotiated in cultures which still live with an enchanted worldview. ${ }^{17}$ Most significant for the purposes of this paper is the work of Birgit Meyer whom Taylor cites in A Secular Age (2007:11). In a recent article Meyer describes Taylor's work as making a seminal contribution to the re-framing of religious practice in the contemporary world. ${ }^{18}$ She specifically addresses the enchantment/disenchantment issue and the suggestion that Taylor makes of the necessity of the progressive disenchantment and creation of the buffered self in the process of modernisation. She advocates a more nuanced approach than the direct relationship between disenchantment and modernity that is suggested by Taylor, arguing that Africans have not jettisoned their enchanted worldview but have, in fact, integrated it with modernity. Pentecostalism, for example, has managed to integrate the worlds of power that the spiritual universe brings with modern communication technologies (without which, Meyer suggests, the Holy Spirit can barely manage!), the 'wonders' of market oriented capitalism, the efficient practices of corporate business, and even modern notions of democratic government. 'Spiritualised' versions of the buffered self are constructed in the realm of spiritual warfare where:

the buffered self is in a constant need of being secured by powerful prayer and 'vigilance.' This testifies to an ambivalent understanding of persons as being embedded in and thus permeable to a wider social texture, in which kinship ties are of utmost importance, on the one hand, and as being severable from this texture by creating a kind of spiritual hedge, on the other. In this sense, the convergence of one's own ghJgbJ with

Cornel University Press 1981; David Ray Griffin The Reenchantment of Science - postmodern proposals, State University of New York Press 1988, and David Abram The Spell of the Sensuous - perception and language in a more-than-human-world, Vintage Books, 1996.), represents a fundamental challenge to the modern, rationalist paradigm, precisely on the basis of its propensity for disembeddenness from the world instead of participation in the world. Philosophically the paradigm of choice for these scholars is Phenomenology and Process philosophy (and thus Heidegger, Alfred North Whitehead and company feature more conspicuously in their thinking) rather than Rationality, which finds inspiration in Newton, Descartes, Grotius, Locke and company. Theologically the thrust of the former is toward panentheism and participation while for the latter it is inevitably toward deism or the notion of the hidden God (as in Nürnberger). See, for example, this quote from Ingold:

Are animism and science therefore irreconcilable? Is an animistic openness to the world the enemy of science? Certainly not. I would not want my remarks to be interpreted as an attack on the whole scientific enterprise. But science as it stands rests upon an impossible foundation, for in order to turn the world into an object of concern, it has to place itself above and beyond the very world it claims to understand. The conditions that enable scientists to know, at least according to official protocols, are such as to make it impossible for scientists to be in the very world of which they seek knowledge. Yet all science depends on observation, and all observation depends on participation - that is, on a close coupling, in perception and action, between the observer and those aspects of the world that are the focus of attention. If science is to be a coherent knowledge practice, it must be rebuilt on the foundation of openness rather than closure, engagement rather than detachment. And this means regaining the sense of astonishment that is so conspicuous by its absence from contemporary scientific work. Knowing must be reconnected with being, epistemology with ontology, thought with life. Thus has our rethinking of indigenous animism led us to propose the reanimation of our so-called 'Western' tradition of thought (2011:75).

17 See, for example, John and Jean Comaroff, Modernity and its Malcontents (Chicago: University of Chicago Press. 1993); Adam Ashforth Witchcraft, Violence, and Democracy in South Africa (Chicago: University of Chicago Press, 2005; Gerrie ter Haar and Stephen Ellis, Worlds of Power: Religious Thought and Political Practice in Africa (London: Hurst, 2004).

18 Birgit Meyer, "Religious and Secular, 'Spiritual' and 'Physical' in Ghana”, in What Matters? Ethnographies of Value in a not- so-secular age, (New York: Columbia University Press, 2012, Courtney Bender and Ann Taves [eds.] 86-118). 
12 Reflections around a Zambian Case Study in the Light of Charles Taylor's 'A Secular Age'

the Holy Spirit is understood as an embodiment of power, through which 'spiritual attacks' can be warded off and a person can be made inaccessible to potentially destructive ties (such as witchcraft, inflicted upon by members of one's own family, or possession by family or village gods and other spirits). This occupation, in turn, materialises in tangible assets such as wealth and health (2012:94).

Clearly, such a scenario suggests that the processes that Taylor links so intimately with the creation of modernity, that is the movement from the porous to the buffered self, the rise of the disciplinary society, and the 'great disembedding', are either avoided or integrated into an enchanted universe without sacrificing the basic goal of human flourishing. But, from a development perspective, this is precisely where the problems might occur, as Parsons' work suggests. It is difficult, at least for Westerners, to see how rationalisation, in the strictly Weberian sense of the word, can be replaced by or integrated into, the capricious world of spirits, especially when it comes to productivity, efficiency, and the 'bottom line' of the Western worldview. Clearly, more recognition of these dynamics needs to be done when it comes to Development Theory and Practice in societies still operating with an enchanted universe, because neither the spirits nor the need for development are going to go away any time soon. ${ }^{19}$

19 For more on this topic see Anthony Balcomb, “Truly! But God has told us differently - development theory in Africa and the crisis of alterity”, forthcoming in the Steve de Gruchy festschrift edited by James Cochrane and Isabel Phiri. 